\title{
Electrochemical Evidences of the Inhibitory Action of Propargyl Alcohol on the Electrooxidation of Nickel in Sulfuric Acid
}

\author{
Zilda Baratto Vendrame, and Reinaldo Simões Gonçalves* \\ Universidade Federal de Santa Maria, C.P. 5061, 97105-900 Santa Maria - RS, Brazil
}

Received: March 31, 1997

\begin{abstract}
Neste trabalho são apresentados os resultados dos estudos do comportamento eletroquímico do eletrodo de níquel em $\mathrm{H}_{2} \mathrm{SO}_{4}$ 1,0 N, na ausência e na presença de álcool propargílico (Propin-2-ol-1). Observou-se uma forte interação entre o composto orgânico e a superfície do eletrodo. A incidência de um feixe de luz policromática afeta o processo de transferência de carga sobre o mesmo. Os processos anódicos, associados à eletrooxidação da superfície do eletrodo, foram inibidos com a presença de álcool propargílico no meio. Esta interação aumenta quando o sistema está sob iluminação. A ação inibidora do álcool propargílico foi observada mesmo em soluções de ácido sulfúrico aeradas e a $30^{\circ} \mathrm{C}$.
\end{abstract}

The electrochemical behavior of a nickel electrode in $0.5 \mathrm{M} \mathrm{H}_{2} \mathrm{SO}_{4}$ in the absence and presence of propargyl alcohol (2-Propyn-1-ol) was investigated. Three different electrochemical methods were used in this paper: potentiometry, partial polarization curves and cyclic voltammetry. A strong interaction between the organic compound and the electrode surface was observed. The incidence of polychromatic light on the electrode surface affects the charge transfer process on it. The anodic reactions related to the electrooxidation of the electrode surface were inhibited by the presence of propargyl alcohol in the medium. The interaction between the organic compound and the electrode surface increases when the system is under illumination.

The inhibitory action of propargyl alcohol on the electrooxidation reactions of nickel was observed even at $30{ }^{\circ} \mathrm{C}$ in aerated sulfuric acid.

Keywords: nickel, propargyl alcohol, photoeffects, corrosion inhibitor

\section{Introduction}

The electrochemical behavior of nickel in aqueous solutions is complex. It depends on the ionic composition of the medium, the crystal orientation, thermal treatments and on the perturbation applied to the metal/solution interface. Electrochemical studies confirm that the kinetics of the $\mathrm{Ni}$ electrode involves the presence of adsorbed hydroxo-spe$\operatorname{cies}^{1}$.

Nickel passivation in acid solutions containing a high concentration of sulfate and nickel ions was explained by reaction pathways involving hydroxo- and oxo-species as reaction intermediates ${ }^{2}$.

The behavior of freshly generated electrode surface of $\mathrm{Ni}$ at low potential, shows that a monolayer of $\mathrm{NiOH}$ is formed. Passivation of nickel at high potentials is controlled by the nickel oxide component of the film ${ }^{3}$.
The resistivity of the film formed during the anodic oxidation of nickel in $1.0 \mathrm{~N} \mathrm{H}_{2} \mathrm{SO}_{4}$ solution suggests the presence of $\mathrm{NiO}^{4}$.

The existence of anions on the passive film, formed on a nickel surface in acid solutions, confirms the mechanism involving competition between the species ${ }^{5,6}$.

Some studies have been made with propargyl alcohol as a corrosion inhibitor in acid media for iron and iron alloys $^{7,8}$. The interaction between propargyl alcohol and nickel was studied with respect to the mechanism of inhibition of cathodic evolution of hydrogen ${ }^{9}$. Previous studies state that the corrosion of nickel in $0.5 \mathrm{M} \mathrm{H}_{2} \mathrm{SO}_{4}$ solution was not significantly affected by the presence of propargyl alcohol ${ }^{10}$.

This work intends to characterize the inhibitory ability of propargyl alcohol on the electrooxidation reactions of nickel electrode in deaerated and aerated sulfuric acid.

* Author to whom all correspondence should be addressed 
Three different electrochemical methods were used: a) potentiometry, b) potentiodynamic $\mathrm{I}(\mathrm{E})$ profiles and $\mathrm{c}$ ) partial polarization curves. Some experiments were made in darkness in order to observe the influence of the incidence of polychromatic light on the electrochemical behavior of the metal in the absence and presence of propargyl alcohol.

\section{Experimental}

\section{Electrochemical measurements}

The electrochemical experiments were carried out in a three-electrode electrochemical cell with a platinum counterelectrode and a saturated $\mathrm{Ag} / \mathrm{AgCl}$ electrode as reference. The working electrodes were made from pure nickel foil $99.5 \%$ (Carlo Erba). The samples were cut in rectangles. The active surface of the electrode was not fixed and varied from $0.2 \mathrm{~cm}^{2}$ to $0.6 \mathrm{~cm}^{2}$. The electrode preparation is described elsewhere ${ }^{7}$.

The electronic arrangement consisted of a PAR 173 potentiostat with a PAR 376 logarithm current converter, a PAR 175 universal programmer and a PAR RE0089 X-Y recorder.

Potentiometric experiments were made with a digital pH meter Philips (PW9409) coupled with a X-t recorder Varian model A-25.

Some experiments were made in darkness and, for comparison, with illumination. The polychromatic light source was a slide projector with a $150 \mathrm{~W}$ bulb. The light beam was collimated to shine directly on the electrode surface by using a glass lens.

\section{Electrolyte preparation}

The $0.5 \mathrm{M} \mathrm{H}_{2} \mathrm{SO}_{4}$ aqueous solutions were prepared from pure concentrated sulfuric acid (Merck) and distilled water. Before each experiment, the electrolyte was deaerated by bubbling pure nitrogen through the solution. To obtain comparative performance data, some tests were repeated in aerated acid solutions. The propargyl alcohol purity was controlled by periodical distillation.

\section{Results and discussions}

\section{Potentiometric measurements}

The purpose of these experiments was to determine the interaction between the nickel electrode and propargyl alcohol at open-circuit potential conditions. Before each measurement a preactivation of the electrode was applied in the supporting electrolyte. This consisted in a cyclic variation of the potential between $-0.38 \mathrm{~V}(\mathrm{Ag} / \mathrm{AgCl})$ and $-0.030 \mathrm{~V}(\mathrm{Ag} / \mathrm{AgCl})$ at $\mathrm{v}=10 \mathrm{mV} / \mathrm{s}$ during $10 \mathrm{~min}$. The procedure was interrupted and the corrosion potential measured. Propargyl alcohol was added to the deoxygenated supporting electrolyte solution with stirring, and the potential of the electrode was then allowed to attain the steady state condition value (corrosion potential). Typical data showing the changes of the working electrode potential versus time are shown in Fig. 1. The effect of the illumination is also presented.

The corrosion potential shifted to a more positive value instantaneously. These results are in agreement with that observed with unsaturated organic compounds ${ }^{11}$. This effect suggests that there is a strong interaction between propargyl alcohol and the electrode surface since the corrosion potential changes abruptly with the presence of the organic compound. The difference between the initial and final potential values $(\Delta \mathrm{E})$ is lower in darkness than with illumination. The adsorption/desorption process related to the interaction may depend on the illumination conditions.

The presence of propargyl alcohol may inhibit some anodic reactions that occur on the active sites present in the nickel surface. The adsorption of the organic compound displaces the adsorbed water that is involved in the oxidation mechanism ${ }^{1}$. The effect of the incidence of light in the electrode surface may be related to the water or organic desorption process.

The potential shifts to more positive values and depends on the alcohol concentration. The electrode potential displacement, $(\Delta \mathrm{E})$, was $140 \mathrm{mV}$ when the concentration of PA was $\mathrm{C}_{(\mathrm{PA})}=1.0 \mathrm{mM}$ and $150 \mathrm{mV}$ when $\mathrm{C}_{(\mathrm{PA})}=5.0 \mathrm{mM}$. This difference may suggest that the amount of adsorbed species formed during propargyl alcohol adsorption increases with the organic compound concentration.

This method confirms that the interaction between propargyl alcohol and the nickel surface is fast and stable, and is related with an adsorption process of the organic compound. The electrode coverage depends on the water desorption and alcohol concentration.

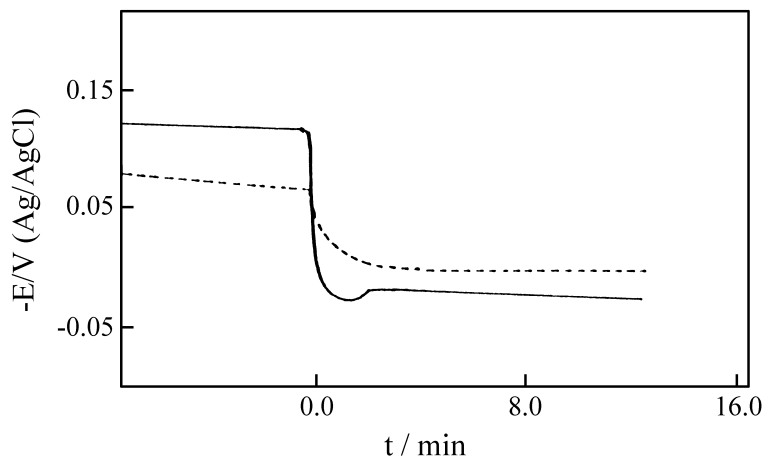

Figure 1. Equilibrium potential changes of nickel electrode in deaerated $0.5 \mathrm{M} \mathrm{H}_{2} \mathrm{SO}_{4}$, at $20^{\circ} \mathrm{C}$, under stirring conditions ( $750 \mathrm{rpm}$ ), versus time. The instant of addition was labelled at time zero, where propargyl alcohol $\left(\mathrm{C}_{\mathrm{AP}}=1.0 \mathrm{mM}\right)$ was added in the medium: $(\square)$ under illumination and (---) in darkness. 
Partial polarization curves - Studies in the absence of propargyl alcohol

\section{The effect of light: a) deaerated acid solutions}

The effect of the light observed in the previous potentiometric studies was explored also by this method in order to verify the influence on the electron-transfer process. At more positive potencials the electrode processes are related to the passive layer formation. This passive film may have semiconductor properties which affect the rate constants for electron transfer at the semiconductor/electrolyte interface. The theoretical aspects of semiconductor electrochemistry are well described in the literature ${ }^{12,13}$.

The current-potential curves under potentiostatic control and in steady state conditions were recorded after an electrode preactivation as described before. Afterwards, a potential program was applied. A potential step at -0.030 $\mathrm{V}(\mathrm{Ag} / \mathrm{AgCl})$ was applied to oxidize some organic material eventually adsorbed on the electrode surface; then a potential step at $-0.38 \mathrm{~V}(\mathrm{Ag} / \mathrm{AgCl})$ was applied in order to reduce the oxide layer formed. After this preactivation period, the process was interrupted and, the open circuit potential of the electrode was then allowed to attain the corrosion potential value. Both anodic and cathodic polarization curves started from the corrosion potential.

The cathodic and anodic partial polarization curves of nickel electrode in deaerated $0.5 \mathrm{M} \mathrm{H}_{2} \mathrm{SO}_{4}$, are shown in Fig. 2. In the potential range between $-0.10 \mathrm{~V}$ and $0.10 \mathrm{~V}$ $(\mathrm{Ag} / \mathrm{AgCl})$ the process is active; the current densities increase with potential. In this potential range an electrooxidation of the electrode is occurring. On the negative side the hydrogen reduction is the main reaction on the electrode surface. The effect of the incidence of polychromatic light on the electrode surface is also presented. The current density values recorded in the positive potential range were

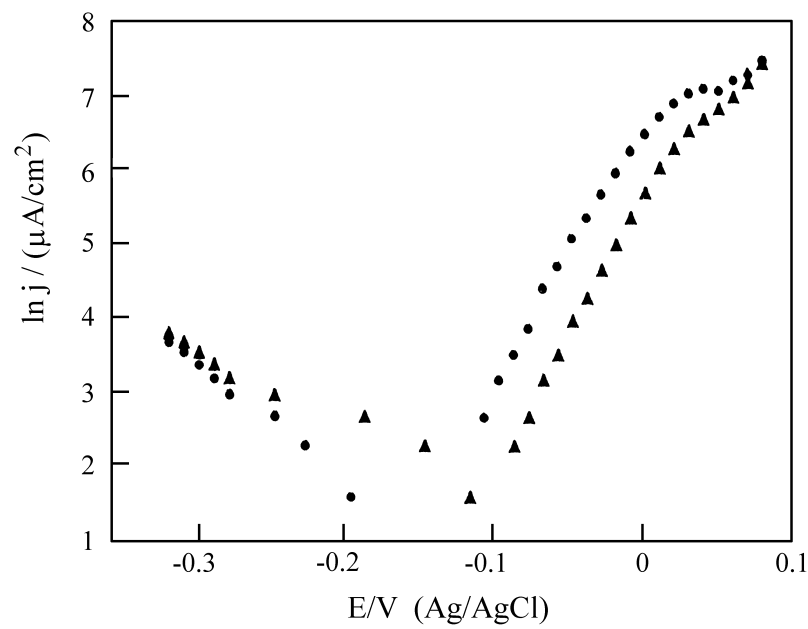

Figure 2. Partial polarization curves of nickel electrode in deaerated $0.5 \mathrm{M} \mathrm{H}_{2} \mathrm{SO}_{4}$, at $25^{\circ} \mathrm{C}$, in static conditions: $(\bullet)$ in darkness and $(\Delta)$ under illumination. lower when the electrode was under illumination than in darkness. Based on the data it is possible to consider:

a)The influence of the light on the passive nickel films may be related with semiconductor capacity to produce electrons and holes in the conduction and valence band, respectively. In buffered $0.5 \mathrm{M} \mathrm{Na}_{2} \mathrm{SO}_{4}$ a photoresponse was observed on nickel passive films. The dependence of the photoresponse on light energy is comparable to that observed on Ni oxides ${ }^{14}$. Some authors found that when the filmed Ni electrode immersed in the Briggs solution was polarized close to and into the hydrogen evolution range, cathodic photocurrents were observed. In this discharge range the electrodes behave as if it were covered with a p-type semiconducting oxide. With the electrode anodically polarized, large photocurrents were observed, pointing to a n-type passivating oxide layer ${ }^{15}$. In $1 \mathrm{M} \mathrm{KOH}$ the authors confirmed that anodic photocurrent from oxidized films of nickel which behave as n-type semiconductors can be generated by visible light of energies as low as $1.5 \mathrm{eV}^{16}$.

However, the data obtained in this work show that anodic currents decrease when the electrode surface is under polychromatic illumination. Since the oxide phase formation depends on the amount of adsorbed water ${ }^{1}$, the effect of the light may be related with water desorption.

b) The anodic behavior of $\mathrm{Ni}$ in acid electrolytes is very complex and depends strongly on the metal purity, on its crystallographic characteristics, on the solution composition and on the type of perturbation applied to the metal/solution interface. The kinetics of the Ni electrodes in acid solutions with a high chloride ion concentration involves an uniform dissolution at low anodic potentials with a probable reaction path ${ }^{1}$ :

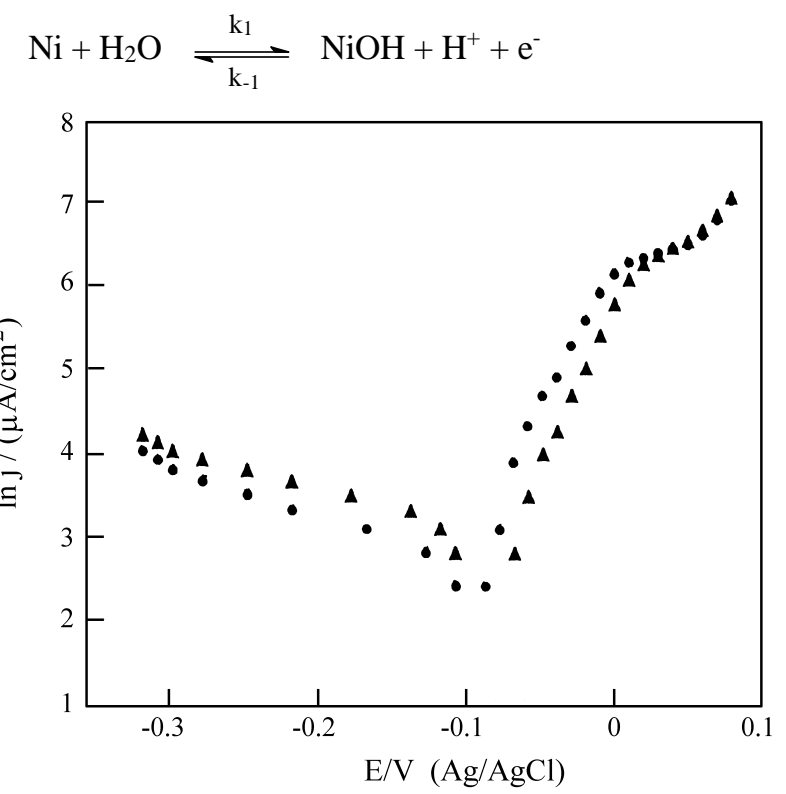

Figure 3. Partial polarization curves of nickel electrode in aerated $0.5 \mathrm{M}$ $\mathrm{H}_{2} \mathrm{SO}_{4}$, at $25{ }^{\circ} \mathrm{C}$, in static conditions: $(\bullet)$ in darkness and $(\Delta)$ under illumination. 


$$
\begin{aligned}
& \mathrm{NiOH}+\mathrm{H}^{+} \underset{\mathrm{k}_{-3}}{\stackrel{\mathrm{k}_{3}}{\rightleftharpoons}} \mathrm{Ni}^{+}+\mathrm{H}_{2} \mathrm{O} \\
& \mathrm{Ni}^{+} \underset{\mathrm{k}_{-2}}{\stackrel{\mathrm{k}_{2}}{\rightleftharpoons}} \mathrm{Ni}^{2+}+\mathrm{e}^{-}
\end{aligned}
$$

which considers the water adsorption process in the mechanism of electrooxidation. This reaction path may be influenced by the incidence of the light, thus decreasing the quantity of adsorbed water as the anodic currents were lower under illumination than in darkness.

The effect of light: b) aerated acid solutions

The results shown in Fig. 3, however, confirm that the incidence of the light on the electrode surface, decreases the anodic current values even in aerated sulfuric acid solutions. This effect may also suggest that the surface reaction rates related to the process of water adsorption are being influenced by the incidence of the light on the electrode surface. The same comments used to explain the effect of the light in deaerated solutions should be applied here.

\section{Partial polarization curves. Studies in the presence of propargyl alcohol}

\section{a) Deaerated acid solutions}

The presence of propargyl alcohol in the medium decreases the current density values as it is shown in Fig. 4. This effect was remarkable in the anodic potential range. The presence of the organic compound inhibits the electrooxidation of the metal in deaerated $0.5 \mathrm{M} \mathrm{H}_{2} \mathrm{SO}_{4}$ over a large potential range. This effect may be related to the adsorption of propargyl alcohol on the active sites, blocking them from the reaction pathway involving water adsorption.

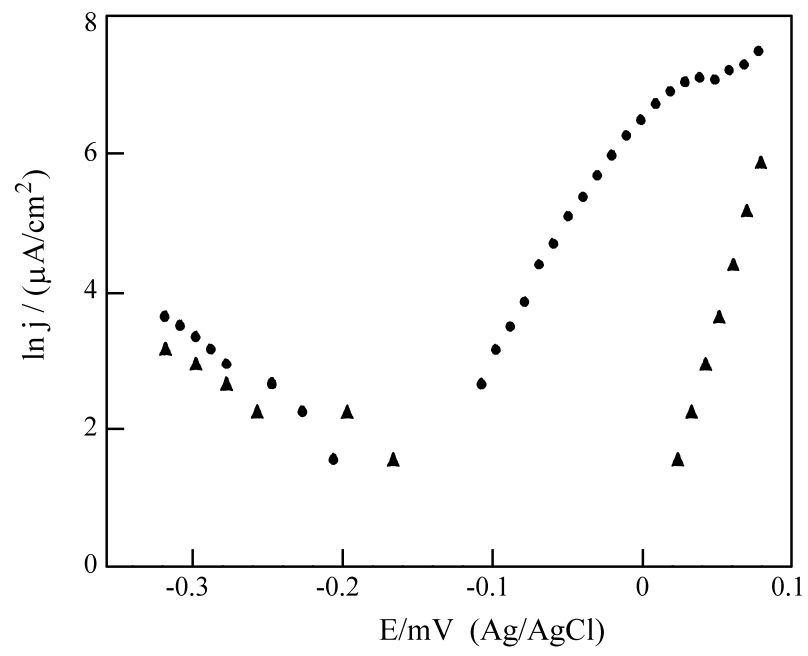

Figure 4. Partial polarization curves of nickel electrode in deaerated $0.5 \mathrm{M} \mathrm{H}_{2} \mathrm{SO}_{4}$, at $25^{\circ} \mathrm{C}$, in darkness: $(\bullet)$ in absence and $(\Delta)$ presence of propargyl alcohol $0.05 \mathrm{mM}$.

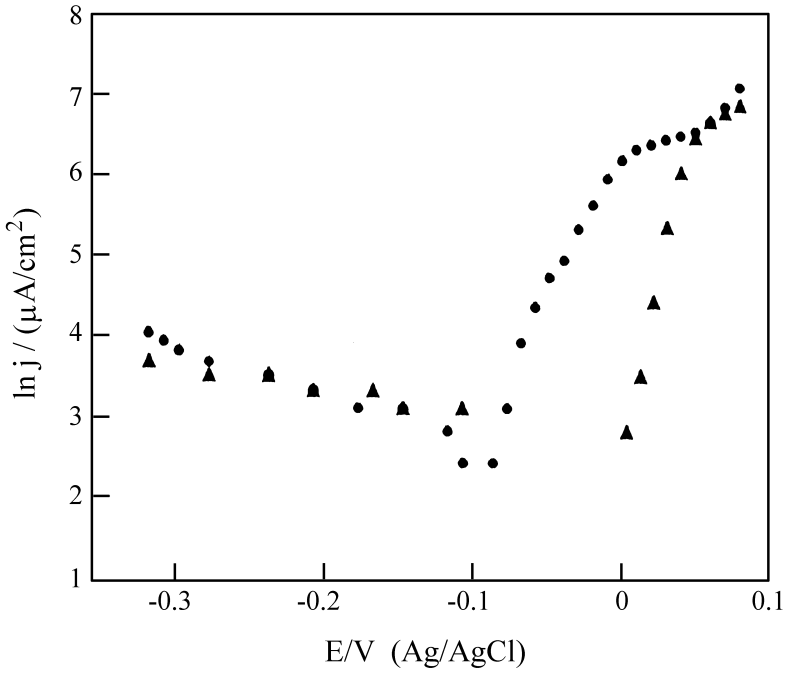

Figure 5. Partial polarization curves of nickel electrode in aerated $0.5 \mathrm{M}$ $\mathrm{H}_{2} \mathrm{SO}_{4}$, at $25^{\circ} \mathrm{C}$, in darkness: $(\bullet)$ in absence and $(\Delta)$ presence of propargyl alcohol $0.05 \mathrm{mM}$.

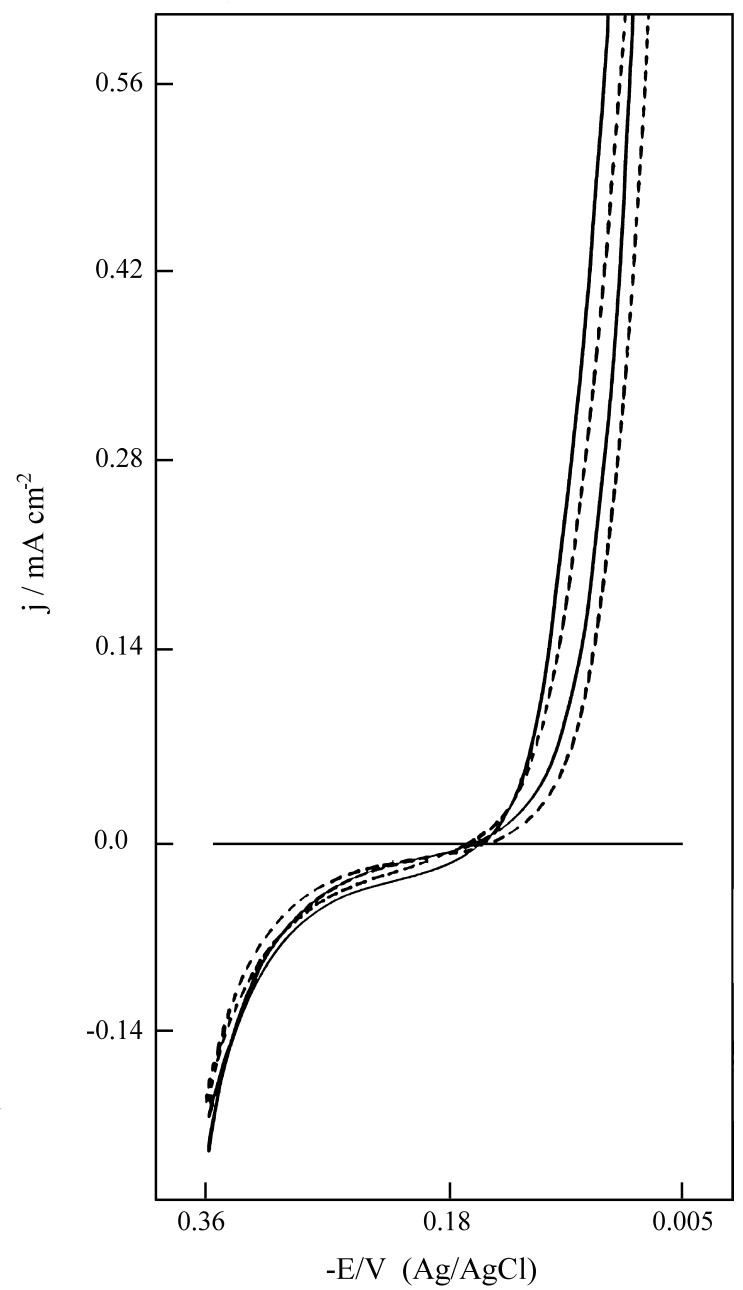

Figure 6. Cyclic voltammograms of nickel in deaerated $0.5 \mathrm{M} \mathrm{H}_{2} \mathrm{SO}_{4}$, at $25{ }^{\circ} \mathrm{C}$ and $\mathrm{v}=2 \mathrm{mV} / \mathrm{s}$ : (-) in darkness and (----) under illumination. 


\section{b) Aerated acid solutions}

The same experiment was made in aerated acid solution. Fig. 5 shows that, even in such aggressive medium, the inhibition effect of the organic compound is evident over the anodic potential range. These results do not agree with those previously published in the literature ${ }^{10}$. This difference may be related to the preactivation procedure and potential program that was applied to the electrode in this work.

\section{Cyclic voltammetric studies}

a) Studies in the absence of propargyl alcohol

Figure 6 shows the $\mathrm{I}(\mathrm{E})$ profiles of the nickel electrode at $25{ }^{\circ} \mathrm{C}$, in deaerated $0.5 \mathrm{M} \mathrm{H}_{2} \mathrm{SO}_{4}$. The effect of the incidence of the light is also presented. The same preactivation procedure was applied on the electrode before each measurement, as described before. In the potential range between $-0.36 \mathrm{~V}$ and $-0.15 \mathrm{~V}(\mathrm{Ag} / \mathrm{AgCl})$ the current densities were related to cathodic processes. On the other side, in the potential range from $-0.15 \mathrm{~V}$ to $-0.005 \mathrm{~V}(\mathrm{Ag} / \mathrm{AgCl})$, the current densities were attributed to the electrooxidation of the electrode. The electrodissolution of the electrode occurs in this potential range ${ }^{11}$.

Some results obtained in the $\mathrm{Ni} / 0.5 \mathrm{~N} \mathrm{H}_{2} \mathrm{SO}_{4}$ suggest that the anodic electrochemical process depends fundamentally on the solvent and acidity of the solution ${ }^{17}$. The authors suggest that these anodic processes are related to the electrodissolution of the metal and to the formation of passivating species. The mechanism involved may be as follows:

$$
\mathrm{Ni}_{\mathrm{x}} \mathrm{Ni}\left(\mathrm{H}_{2} \mathrm{O}\right)=\mathrm{Ni}_{\mathrm{x}} \mathrm{Ni}(\mathrm{OH})+\mathrm{H}^{+}+\mathrm{e}^{-}
$$

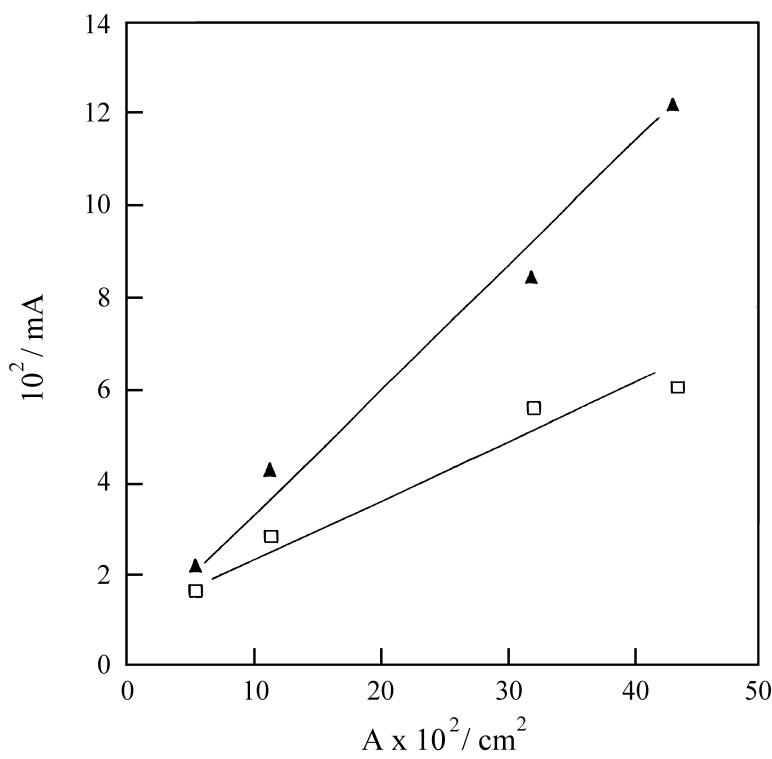

Figure 7. Plot of the currents taken at $\mathrm{E}=-0.23 \mathrm{~V} /(\mathrm{Ag} / \mathrm{AgCl})$ from the voltammograms vs. the geometrical surface area of the nickel electrodes in deaerated $0.5 \mathrm{M} \mathrm{H}_{2} \mathrm{SO}_{4}$, at $25{ }^{\circ} \mathrm{C}$, in darkness $(\square)$ and under illumination $(\Delta)$.

$$
\begin{aligned}
& \mathrm{Ni}_{\mathrm{x}} \mathrm{Ni}(\mathrm{OH})=\mathrm{Ni}_{\mathrm{x}} \mathrm{Ni}(\mathrm{OH})^{+}+\mathrm{e}^{-} \\
& \mathrm{Ni}_{\mathrm{x}} \mathrm{Ni}(\mathrm{OH})^{+}+\mathrm{H}^{+}=\mathrm{Ni}^{2+}+\mathrm{Ni}_{(\mathrm{x}-1)} \mathrm{Ni}\left(\mathrm{H}_{2} \mathrm{O}\right) \\
& \mathrm{Ni}_{\mathrm{x}} \mathrm{Ni}(\mathrm{OH})^{+}+\mathrm{H}_{2} \mathrm{O}=\mathrm{Ni}_{\mathrm{x}}\left[\mathrm{Ni}(\mathrm{OH})_{2}\right]+\mathrm{H}^{+} \\
& \mathrm{Ni}_{\mathrm{x}}\left[\mathrm{Ni}(\mathrm{OH})_{2}\right]=\mathrm{Ni}_{\mathrm{x}}+\mathrm{Ni}^{2+}+2 \mathrm{OH}^{-} \\
&\left.\mathrm{Ni}_{(\mathrm{x}-1)}\left\{2 \mathrm{Ni}(\mathrm{OH})_{2}\right]\right\}= \mathrm{Ni}_{(\mathrm{x}-1)}\left[(\mathrm{NiOOH}) \cdot \mathrm{Ni}(\mathrm{OH})_{2}\right]+ \\
&+\mathrm{H}^{+}+\mathrm{e}^{-}
\end{aligned}
$$

where $\mathrm{Ni}_{\mathrm{x}}$ denotes the bulk metal, the parenthesis and the brackets refer to adsorbed surface species and to film forming species, respectively.

The current density values in the anodic potential range were lower when the electrode is under illumination than in darkness. This effect agrees with that observed with partial polarization curves. Since the water adsorption is involved in the electrooxidation mechanism of the electrode, the same comments should be applied to explain this

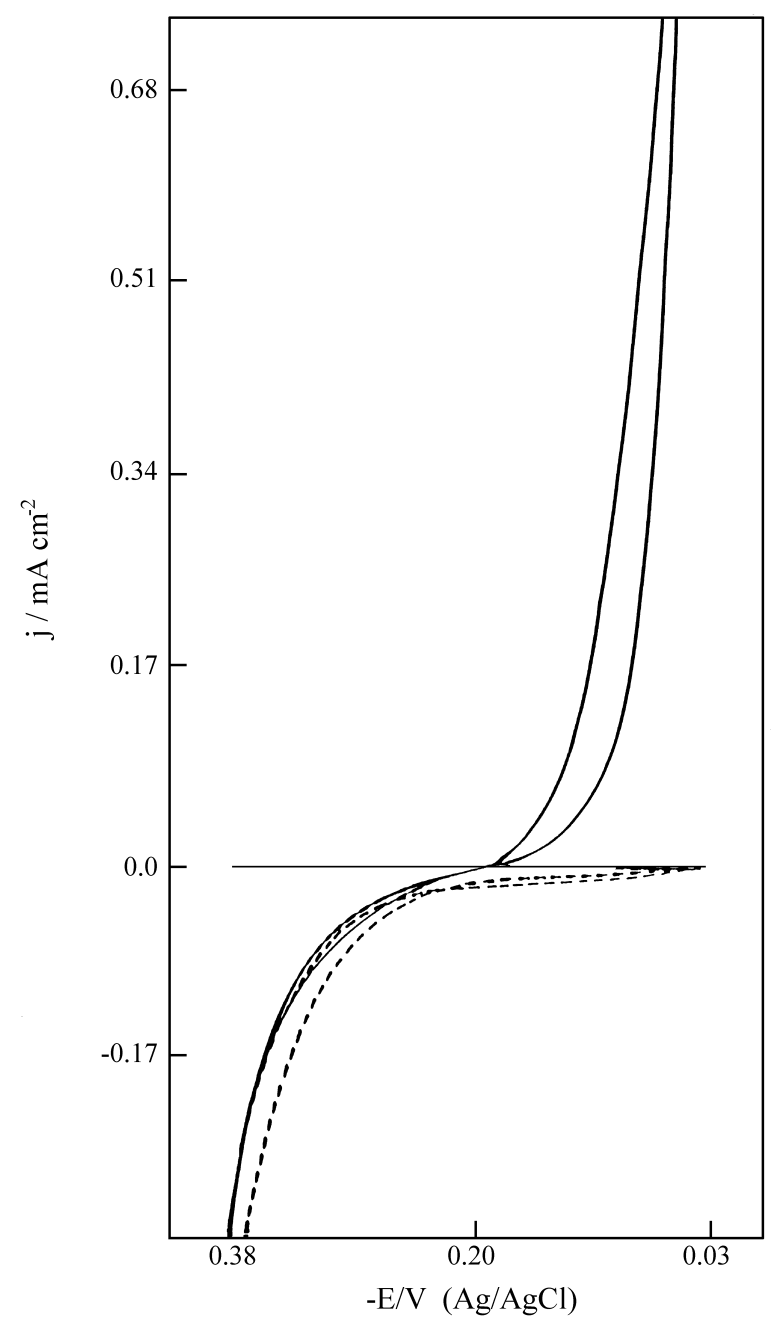

Figure 8. Cyclic voltammograms of nickel in deaerated $0.5 \mathrm{M} \mathrm{H}_{2} \mathrm{SO}_{4}$, at $25{ }^{\circ} \mathrm{C}$ and $\mathrm{v}=2 \mathrm{mV} / \mathrm{s}$, under illumination: (-) in absence and (----) presence of propargyl alcohol $0.05 \mathrm{mM}$. 


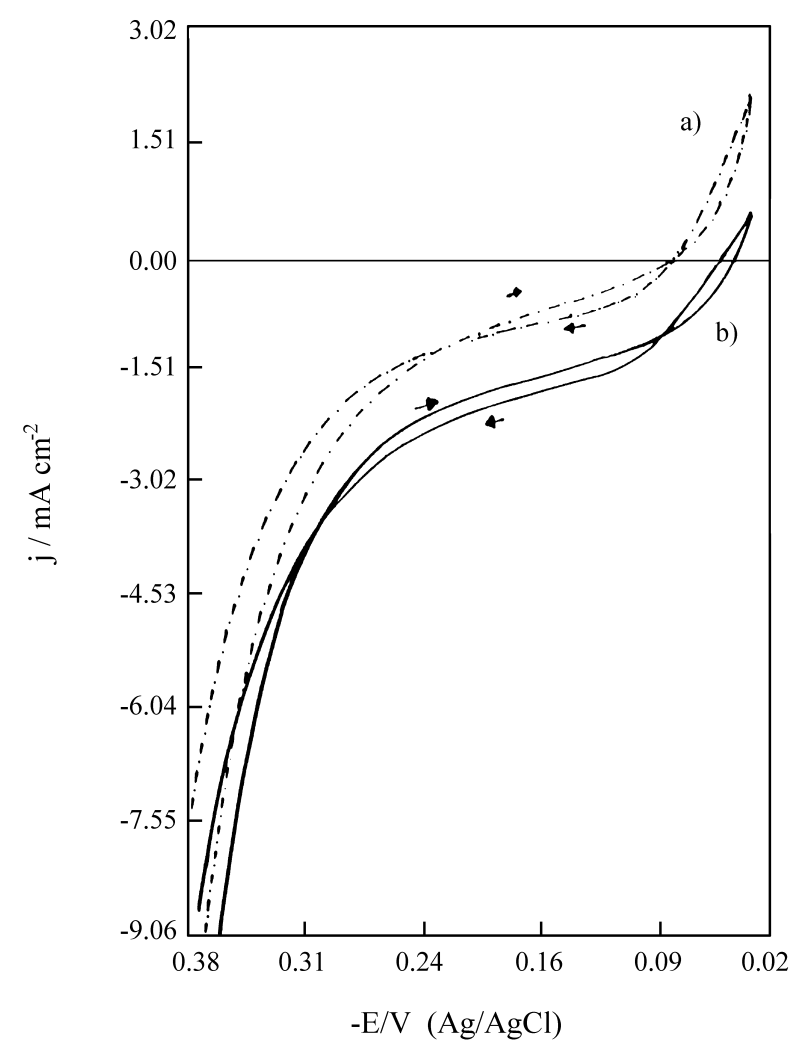

Figure 9. Comparative cyclic voltammograms of nickel in deaerated $0.5 \mathrm{M} \mathrm{H}_{2} \mathrm{SO}_{4}$, at $25^{\circ} \mathrm{C}$ and $\mathrm{v}=2 \mathrm{mV} / \mathrm{s}$, in the presence of propargyl alcohol $0.05 \mathrm{mM}$ : a) in darkness and b) under illumination.

effect. The incidence of polychromatic light decreases the quantity of adsorbed water.

The reproducibility of the data regarding this method is shown in Fig. 7. The current values obtained from the voltammograms versus the geometrical surface areas of the different electrodes are plotted. The current density values vary linearly with the geometrical surface area of the electrodes.

b) Studies in the presence of propargyl alcohol.

Deaerated solutions

The effect of the presence of propargyl alcohol on the $\mathrm{I}(\mathrm{E})$ curves of nickel in deaerated sulfuric acid solutions are shown in Fig. 8. It is notable that the anodic current density values decrease in the presence of the organic compound, indicating that the electrodissolution of the metal was inhibited. The interaction between propargyl alcohol and nickel surface shift the corrosion potential, $\mathrm{E}_{\mathrm{corr}}$, to more positive values.

The same strong interaction was observed using acetylene as inhibitor ${ }^{11}$. The authors explain the results as an adsorption displacement reaction such as:

$$
x_{\mathrm{L}}\left[\mathrm{Ni} y_{\mathrm{L}}(\mathrm{L})_{\mathrm{ads}}\right]+x_{\mathrm{M}} \mathrm{M} \rightarrow x_{\mathrm{M}}\left[\mathrm{Ni} y_{\mathrm{M}}(\mathrm{M})_{\mathrm{ads}}\right]+y_{\mathrm{L}} \mathrm{L}
$$

where $\mathrm{M}$ is the inhibitor adsorbate and $\mathrm{L}$ represents $\mathrm{OH}$ or $\mathrm{H}_{2} \mathrm{O}$ species.

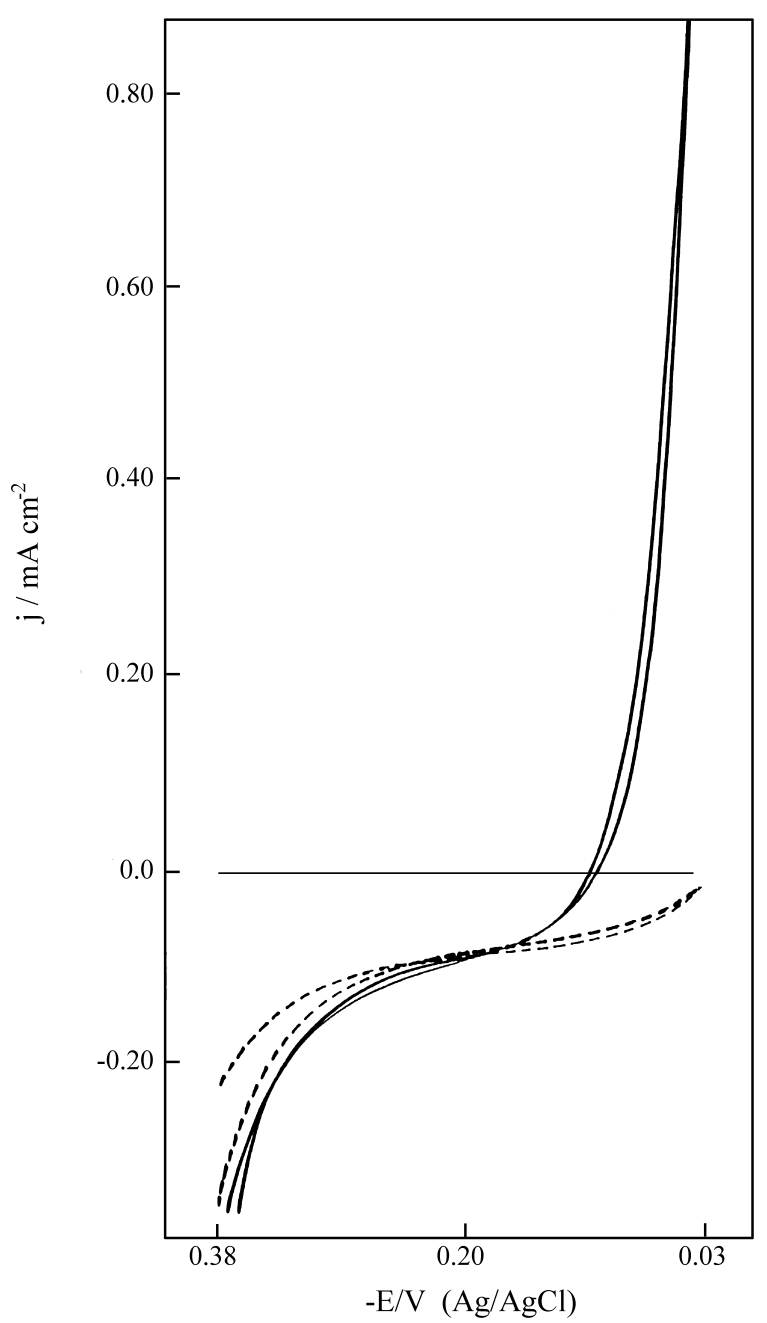

Figure 10. Cyclic voltammograms of nickel in aerated $0.5 \mathrm{M} \mathrm{H}_{2} \mathrm{SO}_{4}$, at $25{ }^{\circ} \mathrm{C}$ and $\mathrm{v}=2 \mathrm{mV} / \mathrm{s}$, under illumination: (-) in absence and (----) presence of propargyl alcohol $0.05 \mathrm{mM}$.

The adsorption of propargyl alcohol on the nickel surface blocks the water adsorption or displaces adsorbed water involved in the corrosion mechanism. The electrodissolution of the metal decreases in the presence of the organic compound as suggested by the voltammograms.

Figure 9 shows the effect of the incidence of polychromatic light on the voltammograms of nickel in the presence of propargyl alcohol. The interaction between the organic compound and the electrode surface improves when the electrode is under illumination since that both cathodic and anodic currents decrease more than in darkness. The anodic current values related to the electrodissolution of the metal were lower under illumination than in darkness. This effect may suggest that the mechanism of inhibition of the corrosion process of nickel by this compound depends on the illumination conditions. The electrooxidation of nickel in the presence of propargyl alcohol starts at more positive potential than in the absence of the inhibitor. This fact may 


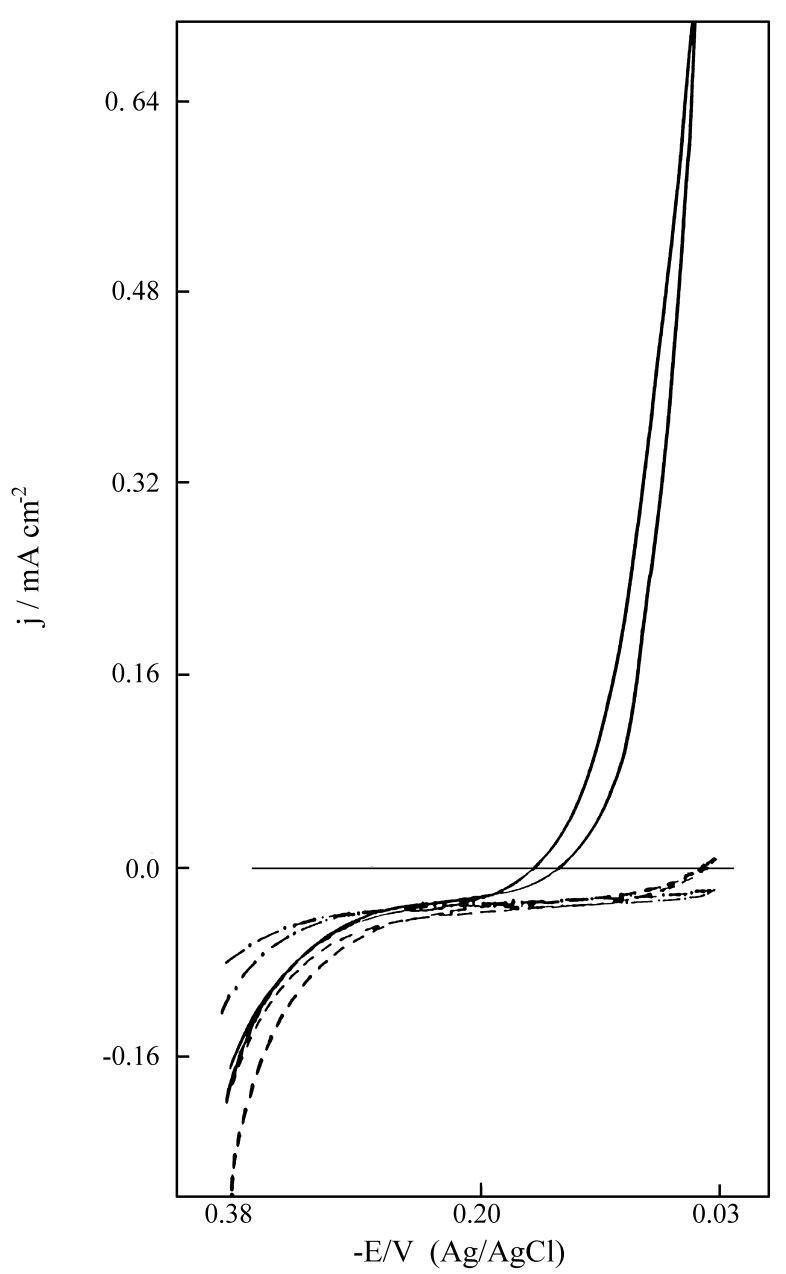

Figure 11. Comparative cyclic voltammograms of nickel in deaerated $0.5 \mathrm{M} \mathrm{H}_{2} \mathrm{SO}_{4}$, at $25^{\circ} \mathrm{C}$ and $\mathrm{v}=2 \mathrm{mV} / \mathrm{s}$, under illumination: (-) in absence of inhibitor at $5{ }^{\circ} \mathrm{C}$; (- - -) in the presence of propargyl alcohol $0.05 \mathrm{mM}$ at $5{ }^{\circ} \mathrm{C}$ and (----) in the presence of propargyl alcohol $0.05 \mathrm{mM}$ at $30{ }^{\circ} \mathrm{C}$.

suggest that more active sites were occupied by the organic compound or that they were liberated by adsorbed water that is involved in the electrodissolution mechanism. No evidence of the effect of the light on the interaction between propargyl alcohol and nickel surface was found in the literature.

c) Studies in the presence of propargyl alcohol. Aerated solutions

Figure 10 shows the effect of the presence of propargyl alcohol on the electrochemical behavior of nickel in aerated sulfuric acid. The inhibition effect of the organic compound was notable even in such aggressive solution. This result agrees with that observed in the partial polarization experiments. The same comments given in deaerated solutions should be applied here to explain the results under these conditions.

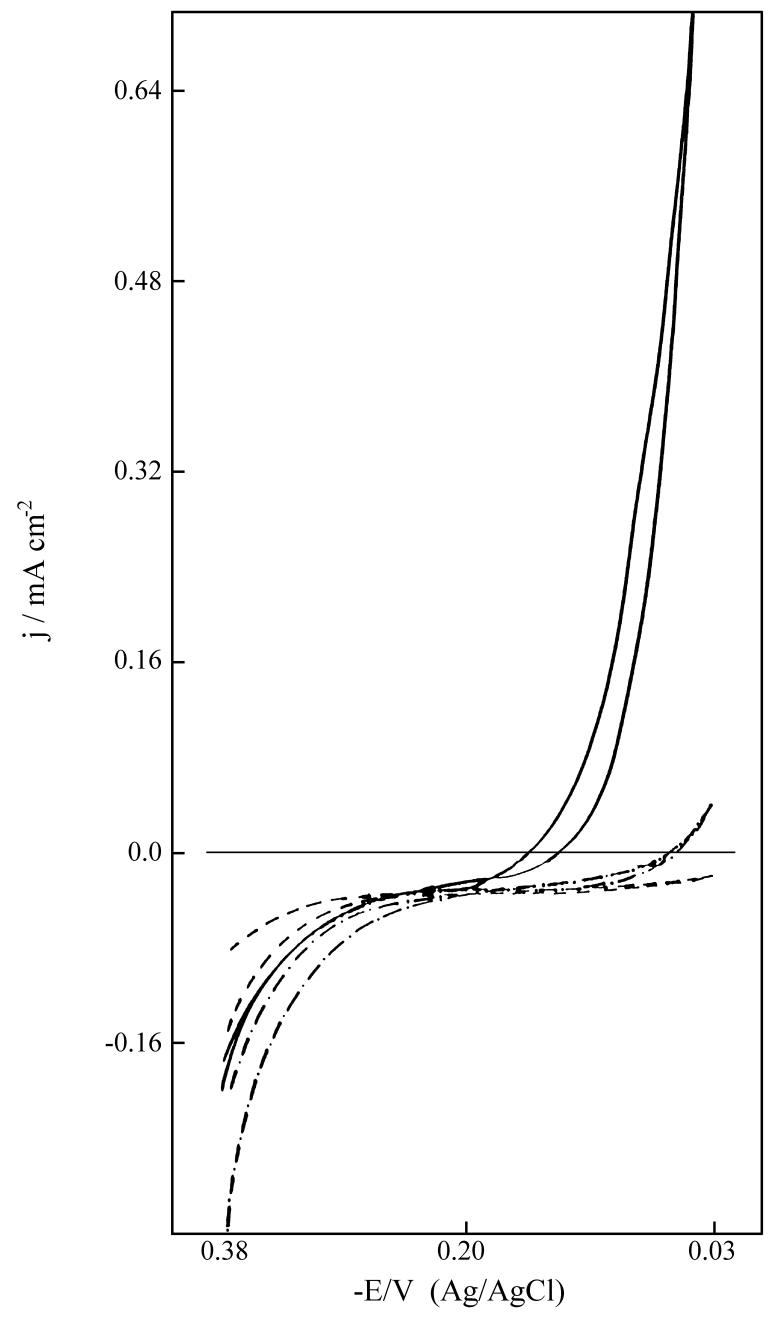

Figure 12. Comparative cyclic voltammograms of nickel in deaerated $0.5 \mathrm{M} \mathrm{H}_{2} \mathrm{SO}_{4}$, at $25{ }^{\circ} \mathrm{C}$ and $\mathrm{v}=2 \mathrm{mV} / \mathrm{s}$, in darkness: (一) in absence of inhibitor at $5{ }^{\circ} \mathrm{C}$; (----) in the presence of propargyl alcohol $0.05 \mathrm{mM}$ at $5{ }^{\circ} \mathrm{C}$ and (- - ) in the presence of propargyl alcohol $0.05 \mathrm{mM}$ at $30{ }^{\circ} \mathrm{C}$.

d) Studies in the presence of propargyl alcohol. Different temperatures

The effect of the temperature was investigated to determine if the interaction between the organic compound and the electrode surface decreases when the temperature increases. Fig. 11 shows the voltammograms of nickel in the absence of propargyl alcohol at $5{ }^{\circ} \mathrm{C}$ and, comparatively, in the presence of the organic compound at $5{ }^{\circ} \mathrm{C}$ and $30^{\circ} \mathrm{C}$ keeping the system under illumination. The inhibitory performance was not strongly influenced by the temperature increase, as is shown by the low anodic current density values observed.

The same experiments were repeated in darkness as is shown in Fig. 12. The inhibitor interaction of the organic compound was noticeable also under these conditions. However, the inhibitory effect was lower in darkness than under illumination. 


\section{Conclusions}

The data obtained by different methods confirm that the illumination of nickel can affect the electrochemical behaviour of the metal in $0.5 \mathrm{M} \mathrm{H}_{2} \mathrm{SO}_{4}$. The interaction between propargyl alcohol and the electrode surface changes the corrosion potential remarkably in deaerated sulfuric acid.

The results observed from partial polarization curves confirm the inhibitory effect of propargyl alcohol even in aerated sulfuric acid solutions.

The cyclic voltammetric method shows that anodic currents related to the electrooxidation process of the metal decrease strongly in the presence of propargyl alcohol. The interaction electrode/organic compound was greater when the electrode was under illumination than in darkness. The inhibitory effect was observed even when the aerated sulfuric acid solution was at $30^{\circ} \mathrm{C}$.

\section{Acknowledgments}

The authors thank to CNPq, CAPES and GTZ/Germany for financial support.

\section{References}

1. Vilche, J.R.; Arvia, A.J. Corrosion Science 1975, 15, 419.

2. Vilche, J.R.; Arvia, A.J. Corrosion Science 1978, 18, 441.
3. Misra, R.D.; Burstein, G.T. Corrosion Science 1984, 24,305 .

4. Zamin, M.; Ives, M.B. J. Electrochem. Soc. 1979, 126, 470.

5. Melendres, C.A.; Tani, B.S. J. Electrochem. Soc. 1986, 133, 1059.

6. Real, S.G.; Barbosa, M.R.; Vilche, J.R.; Arvia, A.J. J. Electrochem. Soc. 1990, 137, 1696.

7. Spinelli, A.; Gonçalves, R.S. Corrosion Science 1990, $30,1235$.

8. Gonçalves, R.S.; Baratto, Z.M., Riegel, I.C.; Spinelli, A. An. Acad. Bras. Ci. 1991, 63, 345.

9. Reshetnikov, S.M. Protection of Metals 1981, 17, 174.

10. Aksut, A.A., Corrosion - NACE 1984, 40, 418.

11.Zinola, C.F.; Castro Luna, A.M. Corrosion Science 1995, 37, 1919.

12. Wilhelm, S.M.; Hackerman, N. J. Electrochem. Soc. 1981, 128, 1668.

13. Madou, M.J.; McKubre, M.C.H. J. Electrochem. Soc. 1983, 130, 1056.

14. Carpenter, M.K.; Corrigan, D.A. J. Electrochem. Soc. 1989, 136, 1022.

15. Real, S.G.; Vilche, J.R.; Arvía, A.J. Corrosion Science 1980, 20, 563. 